\title{
ECONOMICS STORY BOOK TO GIVE BASIC ECONOMIC RASIONALITY FROM AN EARLY AGE
}

\section{Aditya Dewantari, Eka Prayudhista}

Sekolah Tinggi Teknologi Kedirgantaraan Yogyakarta aditya.dewantari@gmail.com

\section{Article History}

accepted 09/07/2018

approved 01/08/2018

published 17/09/2018

\section{Keywords}

economics, story book, early age

\begin{abstract}
The role of schools in providing economic education from an early age should be maximized through non-formal or informal education as new economic education begins to be taught in the earliest schools at Junior High School level. In this research will be developed a story book in which contains a message on how to conduct economic activities in a rational manner so that children understand and can apply it in everyday economic activities. This research is a development research using Design Based Research development model. Based on the results of this study it is found that economic storybooks that have been developed are feasible to be used with the percentage of assessment from material experts of $86.72 \%$ (very feasible), and the percentage of assessment from media experts of $90.20 \%$ (very feasible). In addition, this story book is also effective to provide knowledge about the economic rationality that can be seen from the field trial results with a percentage of success of $80 \%$ (very good).
\end{abstract}

Social, Humanities, and Education Studies (SHEs): Conference Series https://jurnal.uns.ac.id/shes

p-ISSN 2620-9284 e-ISSN 2620-9292 


\section{PENDAHULUAN}

Kegiatan sehari-hari yang dilakukan oleh manusia tidak akan pernah terlepas dari persoalan ekonomi. Setiap hari manusia akan melakukan kegiatan ekonomi, baik kegiatan produksi, kegiatan konsumsi, ataupun kegiatan distribusi. Kegiatan ekonomi yang dilakukan oleh setiap individu sehari-hari akan sangat ditentukan oleh pengetahuan yang dimiliki individu tersebut tentang ekonomi. Pengetahuan yang dimiliki oleh setiap individu tentang ekonomi akan terlihat dari rasional atau tidaknya dalam melakukan kegiatan ekonomi. Perilaku individu yang melakukan kegiatan ekonomi secara tidak masuk akal, misalnya menghabiskan pendapatan hanya untuk bersenang-senang tanpa mempertimbangkan aspek kebutuhan lainnya, spekulatif dan untuk berjaga-jaga, sehingga pendapatan yang seharusnya dapat dialokasikan untuk memenuhi seluruh kebutuhan tidak mencukupi, dan terpaksa melakukan hutang.

Wawasan ekonomi dapat ditingkatkan melalui pendidikan ekonomi. Secara umum pendidikan ekonomi bisa diajarkan disemua jalur pendidikan. Sesuai dengan yang tercantum pada UU No. 20 Tahun 2003 Pasal 13 Ayat 1 bahwa jalur pendidikan terdiri dari pendidikan formal, nonformal dan informal.

Pendidikan ekonomi untuk anak bisa dilakukan di lingkungan formal melalui pembelajaran mata pelajaran ekonomi di sekolah. Peran sekolah dalam memberikan pendidikan ekonomi harus dimaksimalkan melalui pendidikan nonformal ataupun informal dikarenakan pendidikan ekonomi baru mulai diajarkan di sekolah paling awal ditingkat Sekolah Menengah Pertama (SMP), padahal pendidikan ekonomi ini seharusnya diajarkan sejak dini karena menjadi bekal seseorang dalam bertindak atau berperilaku ekonomi dalam menjalani kehidupan sehari-hari.

Pengertian anak berdasarkan dimensi usia kronologis sebagaimana dikemukakan National Association for The Education for Young Children (NAEYC) dalam Aisyah (2008:13) bahwa anak usia dini adalah anak yang berada pada rentang usia O-8 tahun, yang tercakup dalam program pendidikan di taman penitipan anak, penitipan anak pada keluarga, pendidikan prasekolah baik swasta maupun negeri, TK, dan SD. Ridho, dkk (2015) menjelaskan Pada rentang usia dini anak mengalami masa keemasan (the golden years) yang merupakan masa ketika anak mulai peka/sensitif untuk menerima berbagai rangsangan. Mulyasa (2012: 16) berpendapat bahwa anak usia dini memiliki rentang usia yang sangat berharga dibanding usia-usia selanjutnya karena perkembangan kecerdasannya sangat luar biasa. Dengan menggunakan metode dan media pembelajaran yang tepat pada usia ini anak akan lebih mudah untuk meresap berbagai pengetahuan ekonomi dasar sebagai pondasi mereka dalam berperilaku ekonomi.

Salah satu metode pembelajaran yang tepat untuk pengembangan anak usia dini adalah metode bercerita atau mendongeng. Menurut Aziz (2017: 129) manfaat mendongeng diantaranya: mendongeng dapat mengembangkan imajinasi anak, menambah pengalaman, melatih daya konsentrasi, menambah pembendaharaan kata, menciptakan suasana yang akrab, melatih daya tangkap, mengembangkan perasaan sosial, mengembangkan emosi anak, berlatih mendengarkan, mengenal nilai-nilai yang positif dan negatif, serta menambah pengetahuan, Murtiningsih (2001) mengatakan bahwa kegiatan bercerita dapat mengembangkan kreativitas anak, melatih anak untuk berpikir kritis, kreatif dan bertanggung jawab, serta sikap menghargai. Cerita akan lebih mereka ingat dari pada hafalan mata pelajaran tertentu. Sebagai media pendukung dalam metode bercerita ini maka peneliti akan menyusun sebuah pengembangan media pembelajaran ekonomi dalam bentuk buku cerita sebagai media pembelajaran penunjang untuk menanamkan rasionalitas berekonomi sejak dini pada anak-anak, dengan media pembelajaran yang menarik dan mudah dipahami ini, pendidik akan terbantu dalam memberi wawasan ekonomi sejak dini tanpa harus menunggu anak tersebut memasuki Sekolah Menengah Pertama (SMP) untuk mendapatkan wawasan 
ekonomi yang akan mengajarkan mereka untuk bersikap rasional dalam aktivitas ekonomi.

\section{METODE}

\section{Model Penelitian dan Pengembangan}

Peneliti ini menggunakan pendekatan design based research (DBR) yang memiliki ciri khusus yaitu sebuah model penelitian pengembangan produk berdasarkan kebutuhan dan yang dibutuhkan serta melibatkan dan berkolaborasi dengan pengguna hasil pengembangan (praktisi).

\section{Prosedur Penelitian dan Pengembangan}

1. Secara umum penerapan penelitian menggunakan metode yang sistematis namun fleksibel yang bertujuan untuk meningkatkan praktik-praktik pendidikan melalui analisis derative, desain, pengembangan dan implementasi, berdasarkan kolaborasi antara peneliti dan praktisi secara nyata tanpa adanya rekayasa. Selanjutnya untuk langkah pengembangan dalam penyusunan draft sintaks dan skenario pembelajaran dan uji kelayakan prototipe juga melibatkan tim kolaborasi.

2. Aplikasi Design Based Research dalam pengembangan ini peneliti mengadaptasi dari model Fase yang dikembangkan Preffers er al. (2007), seperti dikutip dalam Elly\&Levy (2010:11) (dalam Witjaksono, 2010:112). Berikut ini diagram alur prosedur penelitian dan pengembangan yang akan dilaksanakan pada penelitian ini: 


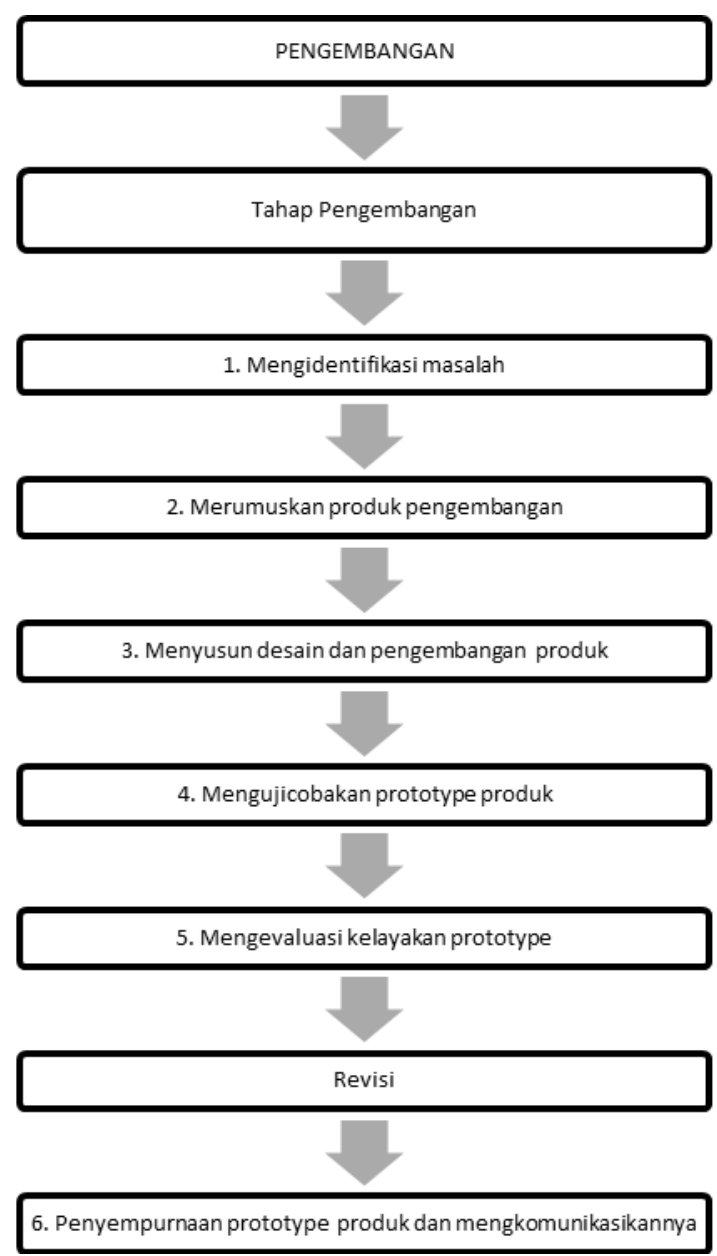

Gambar 1. Alur Pengembangan Economics Story Book untuk Menanamkan Rasionalitas Berekonomi Sejak Dini

\section{Uji Coba Produk}

Produk pengembangan ini diujicobakan pada 30 anak rentang usia 5 sampai 8 tahun.

\section{Analisis Data}

Analisis penelitian ini dilakukan dengan cara:

1) Uji kelayakan Economics Story Book yang dikembangkan untuk digunakan

2) Pengimplementasian Economics Story Book

3) Pengukuran keefektifan Economics Story Book yang dikembangkan dari segi pemahaman anak terhadap rasionalitas berekonomi 


\section{HASIL DAN PEMBAHASAN}

Hasil dari tiap-tiap fase dalam pengembangan buku cerita ekonomi ini adalah sebagai berikut:

1. Identifikasi Masalah dan Assesmen Kebutuhan

Hasil identifikasi masalah yang didapatkan pada lapangan yaitu pembelajaran ekonomi yang secara formal baru diberikan pada saat siswa duduk di bangku Sekolah Menengah Pertama harus didukung melalui kegiatan pembelajaran non formal maupun informal karena pengetahuan mengenai ekonomi sangatlah penting untuk menentukan sikap masyarakat dalam menentukan pilihan dan melakukan berbagai kegiatan ekonomi yang pada akhirnya juga berdampak pada perekonomian negara. Menanamkan rasionalitas berekonomi sejak dini merupakan salah satu upaya untuk mengubah masyarakat agar menjadi lebih bijak dalam berekonomi. Buku cerita ekonomi merupakan media yang cocok untuk memberikan pengetahuan dan pemahaman pada anak tentang dasar-dasar ilmu ekonomi.

\section{Merumuskan Produk Pengembangan Economics Story Book untuk Menanamkan Rasionalitas Berekonomi Sejak Dini}

Perumusan pengembangan economics story book ini disusun sesuai dengan karakteristik belajar anak usia dini yakni disusun secara menarik dan dapat menjadi media belajar yang menyenangkan dan mudah dipahami oleh anak-anak. Buku cerita ini memuat teori ekonomi dasar dengan menggunakan cerita dan gambar-gambar guna mempermudah anak dalam memahami bagaimanakah seharusnya mereka berperilaku ekonomi dalam kehidupan sehari-hari dan menerapkannya secara berkelanjuatan sehingga hal tersebut menjadi perilaku positif yang kelak akan membawa dampak positif pula bagi perekonomian negara.

Pemilihan materi dalam pengembangan economics story book ini diambil berdasarkan hasil wawancara kepada praktisi yang dalam penelitian ini adalah guru Sekolah Dasar yang memahami kendala yang dihadapi oleh anak-anak pada rentang usia 5 sampai 8 tahun mengenai pemahaman akan ilmu ekonomi. Dari hasil wawancara tersebut materi yang akan dituangkan dalam economics story book ini dibagi menjadi dua yakni sebagai berikut:

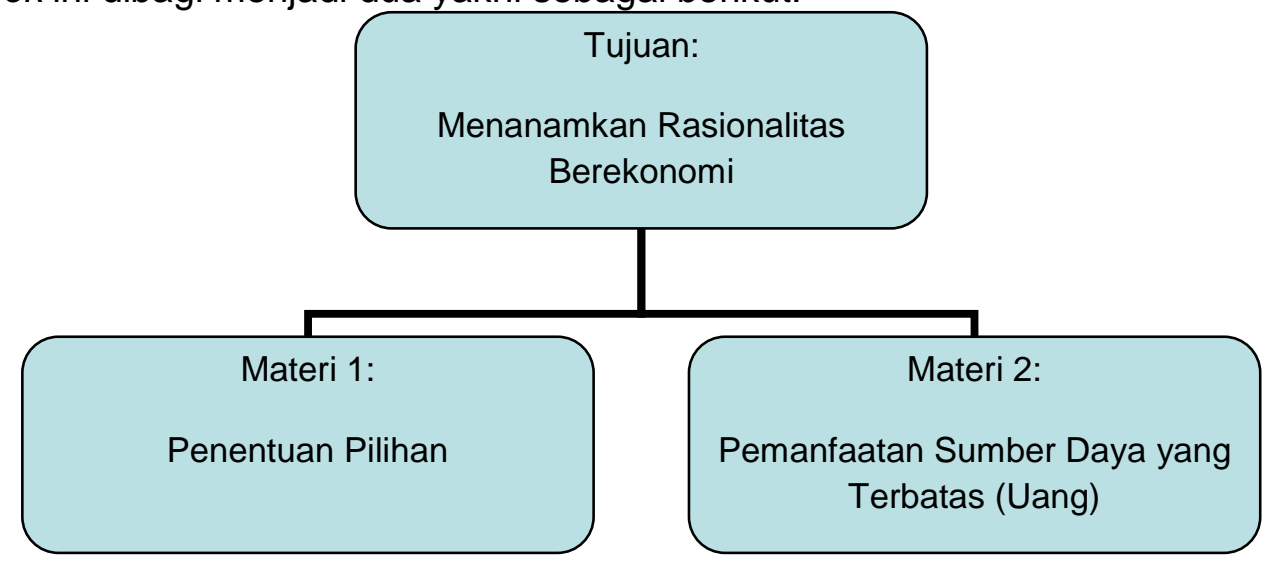

Gambar 2. Rumusan Materi Pengembangan Economics Story Book 
3. Penyusunan Produk Pengembangan Economics Story Book untuk Menanamkan Rasionalitas Berekonomi Sejak Dini

Economics story book disusun melalui beberapa tahapan sebagai berikut:

5. Finishing

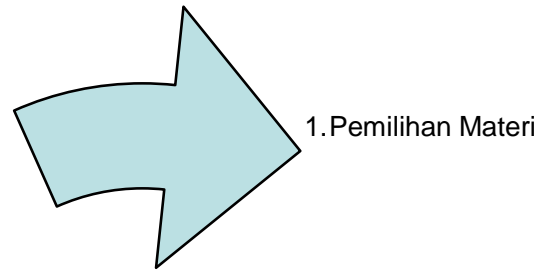

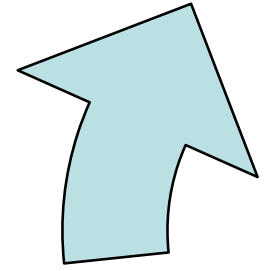

4. Penyusunan Layout

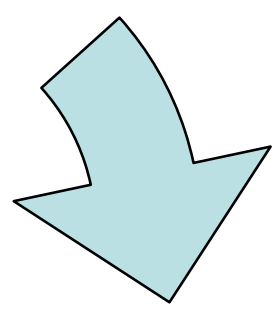

2. Penyusunan Story Board

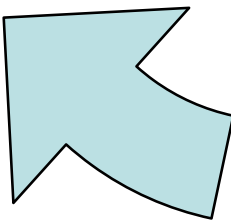

3. Pembuatan
Gambar Animasi

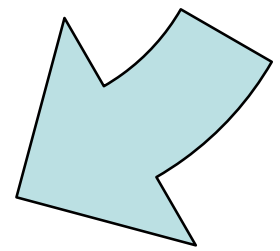

\section{Gambar 3. Tahapan Pengembangan Economics Story Book}

Setiap tahapan pengembangan economics story book dilakukan dengan seksama untuk mendapatkan hasil yang maksimal dan sesuai dengan tujuan pembembangan. Lima tahapan ini dilakukan peneliti bersama-sama dengan praktisi (guru), kartunis, dan ahli media guna mendapatkan kritik saran dan masukan yang dapat menyempurnakan Economics Story Book yang dikembangakan.

4. Uji Coba Produk Pengembangan Economics Story Book untuk Menanamkan Rasionalitas Berekonomi Sejak Dini

Hasil Validasi dari Ahli Materi dan Ahli Media mengenai economics story book yang telah dikembangkan sebagai berikut:

Tabel 1. Hasil Validasi Ahli

\begin{tabular}{cccc}
\hline No & Validator & Prosentase & Keterangan \\
\hline 1 & Ahli Materi & 86.72 & Sangat Layak \\
2 & Ahli Media & 90.20 & Sangat Layak \\
\hline
\end{tabular}


Ahli Materi menyatakan bahwa economics story book yang telah dikembangkan mencapai tingkat kelayakan sebesar $86.72 \%$ atau dengan kata lain sangat layak untuk menanamkan rasionalitas berekonomi sejak dini. Sedangkan ahli media menyatakan bahwa economics story book yang telah dikembangkan mencapai tingkat kelayakan sebesar $90.20 \%$ atau dengan kata lain sangat layak untuk mendjadi media pembelajaran yang mendukung penanaman rasionalitas berekonomi sejak dini.

Economics stiory book ini juga telah melewati uji coba dengan hasil sebagai berikut:

Tabel 2. Hasil Uji Coba

\begin{tabular}{cccc}
\hline No & Uji Coba & Prosentase & Keterangan \\
\hline 1 & Uji Coba Kelompok Kecil & 80.00 & Sangat Layak \\
2 & Uji Coba Lapangan & 80.00 & Sangat Layak \\
\hline
\end{tabular}

Uji coba kelompok kecil dilakukan kepada 5 (lima) anak dengan hasil 80.00\% anak mampu untuk memahami dan menyelesaikan permasalahan ekonomi sederhana yang diberikan dengan baik. Sedangkan hasil uji coba lapangan yang dilakukan kepada 30 (tiga puluh) anak adalah $80.00 \%$ anak mampu untuk memahami dan menyelesaikan permasalahan ekonomomi sederhana yang diberikan sesuai dengan prinsip rasionalitas berekonomi.

\section{Evaluasi Kelayakan dan Mengkomunikasikan Hasil Produk Pengembangan Economics Story Book untuk Menanamkan Rasionalitas Berekonomi Sejak Dini}

Economics story book yang telah dikembangkan dinyakatakan layak baik dari segi materi maupun dari segi media pembelajaran, sehingga produk yang telah dikembangkan ini dapat digunakan sebagai salah satu media pembelajaran untuk menanamkan rasionalitas sejak dini. Buku ini dapat digunakan sebagai penunjang proses pembelajaran formal, informal, maupun non formal dalam pengenalan konsep ekonomi dasar kepada anak.

\section{SIMPULAN}

Dari hasil penelitian ini didapatkan bahwa economics story book yang telah dikembangkan layak untuk digunakan dengan prosentase penilaian dari ahli materi sebesar $86.72 \%$ (sangat layak), dan prosentase penilaian dari ahli media sebesar $90.20 \%$ (sangat layak). Selain itu economics story book ini juga efektif memberikan pengetahuan mengenai rasionalitas berekonomi yang dapat dilihat dari hasil uji coba lapangan dengan prosentase keberhasilan sebesar $80.00 \%$.

Pada penelitan selanjutnya, pengembangan materi yang lebih variatif dirasa perlu untuk dikembangkan menjadi sebuah economics story book yang dapat digunakan sebagai media pembelajaran ekonomi yang mudah dipahami dan menyenangkan bagi anak-anak. 


\section{DAFTAR PUSTAKA}

Aisyah, Siti. 2008. Perkembangan dan Konsep Dasar Pengembangan Anak Usia Dini. Jakarta: Universitas Terbuka.

Aziz, Safrudin. 2017. Strategi Pembelajaran Aktif Anak Usia Dini. Yogyakarta: Kalimedia.

Mulyasa. 2012. Manajemen PAUD. Bandung: PT. Rosdakarya.

Murtiningsih. 2001. Pengembangan Kreativitas Siswa SD Melalui Kegiatan Bercerita, Jurnal IImiah Guru "COPE". No 02. Vol 15.

Ridho, dkk. Jurnal Penelitian Humaniora, Vol. 16, No. 2, Agustus 2015: 59-6. Diakses dari journals.ums.ac.id

UU No. 20 Tahun 2003 Tentang Sistem Pendidikan Nasional

Witjaksono, M. 2010. Peningkatan Kualitas Proses dan Hasil Pembimbingan Skripsi Mahasiswa melalui Implementasi pos-Skripsi. Malang: UM Press. 